\section{Napotkanie przedtekstowego. Budowanie wiedzy etnograficznej o migranckich światach troski}

\author{
Helena Patzer
}

K iedy w czasie badań w Bostonie pytałam moich filipińskich znajomych, dlaczego wyjechali, odpowiadali krótko: „Po to, żeby pomóc rodzinie”, „Ze względu na moje rodzeństwo", „Żeby moja rodzina miała lepszą przyszłość". Kiedy później rozmawiałam z ich krewnymi w filipińskich miastach o planach i marzeniach, oni również roztaczali przede mną wizje wyjazdu z kraju w poszukiwaniu lepszego życia dla bliskich: „Chcę wyjechać za granicę. Chcę wyjechać, żeby pomóc rodzinie". Tę samą logikę można odkryć w narracjach o sobie i w codziennych wyborach - w przypadku migrantek i migrantów rozłączonych ze swoimi rodzinami miłość i poczucie obowiązku ujawniało się w praktykowanej codziennie „trosce na odległość" poprzez wymianę wiadomości i rozmowy przez internet, przekazy pieniężne, przesyłanie paczek i zarządzanie rodzinnym budżetem z zagranicy'.

1 Zob. H. Patzer "Long-distance care. The practice of sustaining transnational ties by Filipino immigrants in Boston", praca doktorska, War-
Helena Patzer - dr, Post-Doctoral Researcher w Instytucie Etnologii Czeskiej Akademii Nauk, adiunkt $w$ Instytucie Etnologii i Antropologii Kulturowej UW. Interesuje się migracją, transnarodowością, krytyczną antropologią rozwoju, studiami miejskimi oraz metodologią badań. Wraz z dr. Tomaszem Rakowskim przygotowała tom Pretextual Ethnographies. Challenging the Phenomenological Level of Anthropological Knowledge-Making, który ukaże się wkrótce w wydawnictwie Sean Kingston Publishing. Kontakt: helenapatzer@wp.pl 
Dług wdzięczności w stosunku do rodziny, lojalność względem niej, stawianie jej potrzeb ponad swoje, to wszystko znane tropy w rodzinnych powiązaniach migrantów. Cechą wyróżniającą migrantów z Filipin jest silny autostereotyp: według niego Filipińczycy jako naród są szczególnie troskliwi, dlatego też zdominowali zawody opiekuńcze, takie jak pielęgniarka, lekarz czy opiekun osób starszych ${ }^{2}$. Zrozumienie tej logiki działania wymaga poznania zasad rządzących codzienną troską o bliskich. Badacz może zdobyć wiedzę o tych zasadach, jeśli znajdzie się w środku przepływów transnarodowych i będzie uczestniczyć w życiu rodzin po obu stronach globu. Szczególna uwaga skierowana jest wtedy na drobne gesty, grymasy i niedopowiedzenia, a także na cielesność badacza i badanych: poprzez "gęste uczestnictwo" (thick participation) 3 badacz staje się sam dla siebie instrumentem zdobywania wiedzy.

Działanie emigrantów wydaje się więc obudowane językiem troski o rodzinę, bez względu na to, czy mówią o tym w kraju docelowym, w czasie wizyty w domu, czy w trakcie rozmów na Skypie. Ta troska o „pozostawionych w kraju" jest częścią bycia członkiem wspólnoty transnarodowej, „transnarodowej wioski", jak nazywa ją Peggy Levitt ${ }^{4}$. Zasady postępowania są tu wyznaczone z góry, jednak dla tych, którzy wyjeżdżają, mogą one być zmienne w czasie: w procesie uczenia się kodu społecznego kraju migracji zdobywają oni nowe umiejętności i przyjmują nowe wartości, które włączają w dawne sposoby budowania relacji z innymi. Przekonstruowanie rozumienia relacji dotyczy tutaj i antropologów, i migrantów: tych, którzy muszą nauczyć się funkcjonowania w nowym kontekście. Wiedza ta, ze względu na swój ucieleśniony charakter, musi być zdobywana poprzez ciało: odpowiednie odgrywanie troski jest bardzo dokładnie obserwowane. W większości przypadków emigrant, działając w paradygmacie troski, ma na uwadze dobro swoich krewnych, jednak jego rozumienie troski znacznie się już różni od tego, jak

Szawa 2015; H. Patzer Unpacking the balikbayan box. Long-distance care through feeding and food-consumption in the Philippines, "Studia Socjologiczne", numer specjalny, red. K. Bielenin-Lenczowska, R. Hryciuk, w druku.

2 Zob. M. Amrith Caring for strangers. Filipino medical workers in Asia, NIAS Press, Copenhagen 2017; C.C. Choy Empire of care. Nursing and migration in Filipino-American history, Ateneo de Manila University Press, Manila 2003.

3 J.K. Samudra Memory in our body. Thick participation and the translation of kinesthetic experience, „American Ethnologist" 2008 no. 35 (4), s. 665-681. 
ją rozumieją członkowie jego rodziny, więc w procesie tym nie dochodzi do porozumienia.

W artykule rozważam, co znaczy „troska” w tym konkretnym kontekście, ale też jak można się jej nauczyć - gdzie są granice właściwego troszczenia się, kto te granice przekracza i jakie są tego konsekwencje (a właściwie po czym poznajemy, że granice są przekroczone). Interesuje mnie więc kwestia metodologiczna - opierając się na transnarodowych badaniach migracji, opisuję, w jaki sposób wiedza o praktykach migrantów i ich rodzin ujawniała się w codziennych interakcjach z nimi i jak tworzyła się w sposób przedtekstowy ${ }^{5}$, zanim jeszcze mogłam ją nazwać i opisać. Aby zrozumieć, czym może być troska, staram się uchwycić momenty, w których ktoś wychodzi poza przyjęte normy i jak to prowokuje innych do przetworzenia własnego rozumienia tego słowa tak, by pomieścić w nim także i to zachowanie. Ponieważ normy są ucieleśnione - $\mathrm{w}$ wielu przypadkach przedtekstowe - proces nauki odbywa się za pośrednictwem powolnego włączania w praktyki kulturowe, testowanie granic, momenty wzajemnego niezrozumienia. W sytuacji nacechowanej mobilnością i zmianą osoba mobilna staje się często narzędziem ujawniającym to, co ukryte, niewypowiedziane, rozumiane bez słów; rodzaj „zażyłości kulturowej" ${ }^{\text {. }}$

Wszystko to, jak dowodzę w artykule, dzieje się na poziomie przedtekstowym, ale niekoniecznie nieuświadomionym. Rodzina zgadza się, by emigrant ją dyscyplinował, co odchodzi od akceptowalnej formy troski, jednak pozwala na to, aby emigrant nie stracił twarzy i nadal mógł być w dobrych relacjach z innymi? . Jak pisze Goffman, wstydzenie się za kogoś może być też rodzajem troski, gdy staramy się nie zwracać uwagi na czyjeś wstydliwe postępowanie, nie reagujemy na nie ${ }^{8}$. To mistrzostwo w troszczeniu się - zachowania, napięcia i powiązania, przedtekstowe w swojej naturze - wydaje mi się znajdować w samym centrum doświadczenia mobilności, jest także fundamentalne dla jego zrozumienia.

5 T. Rakowski, w tym numerze.

6 M. Herzfeld Cultural intimacy. Social poetics in the nation-state, Second edition, Routledge, London - New York 2005.

7 Zob. F. Lynch Social acceptance reconsidered, w: Philippine society and the individual, selected essays by F. Lynch, Revised edition, ed. A.A. Yengoyan, P.Q. Makil, IPC, Ateneo de Manila University, Quezon City 2004 (1973).

8 E. Goffman Embarrassment and social organization, "American Journal of Sociology” 1956 vol. 62 no. 3 , s. 267 . 


\section{Badania: pomiędzy dwoma światami}

Rozpoczynając badania nad transnarodowymi powiązaniami migrantów, wiedziałam, że będę próbowała dotrzeć do tego, co dzieje się po dwóch stronach - jak relacje rodzinne rozumieją członkowie rodziny w Stanach Zjednoczonych i ci pozostający na Filipinach. Zrozumienie, jak kluczowa jest kategoria troski (care), przyszło z czasem, za sprawą obserwacji, powtarzalności, naśladowania, nieporozumień, a nawet konfliktów. Uczestnicząc przez jakiś czas w życiu w obu miejscach, dowiadywałam się, jak ludzie troszczą się na odległość w codziennym życiu, jakie trudności napotykają, co im pomaga w życiu „okrakiem pomiędzy dwoma światami”" . Proces nabywania tej wiedzy zaczyna się z pierwszymi chwilami w terenie, ale trwa długo po zakończeniu badań - w czasie analizy materiału, tworzenia tekstu, post-fieldwork fieldwork ${ }^{10}$. Idee potrzebują czasu i aktywnej pracy, żeby się wykrystalizować. Częścią tego procesu, choć nie zawsze stojącą w centrum analizy, jest zbieranie historii:

Z reguły przekształcamy te historie lub fragmenty historii w antropologiczne eseje, rozprawy, monografie. Jest to akademicki zwyczaj sięgający wczesnego wieku XVII, kiedy wykształcenie się nauk pociągnęło za sobą "odłączenie wrażliwości", a autorytet naukowy przesunął się z bezpośredniego świadectwa i doświadczenia do abstrakcyjnych i panoptycznych form praktyk dyskursywnych. ${ }^{11}$

Możliwy jest jednak powrót do wrażliwości bezpośredniego świadectwa i doświadczenia oraz zbudowanie antropologicznej wiedzy i autorytetu etnograficznego w inny sposób - poprzez otwarcie na intersubiektywne doświadczenie i szukanie tego, co przedtekstowe. Ten powrót wywołany jest przede wszystkim skupieniem na doświadczeniu badawczym - w moim przypadku poszukiwania metodologiczne były konsekwencją momentów niezrozumienia i tarcia między różnymi światami przeżywanymi, w tym moim i moich rozmówców.

To, co opisuje antropolog, często miało pozostać niewidoczne i nieopisane: gniew, wstyd i dyskomfort, których członkowie badanej społeczności

9

P. Levitt The transnational villagers, s. 21.

Zob. A. Cohen Post-fieldwork fieldwork, "Journal of Anthropological Research" 1992 vol. 48, S. 339-354.

M. Jackson Minima ethnographica. Intersubjectivity and the anthropological project, The University of Chicago Press, Chicago 1998, s. 33. 
najchętniej nie pokazywaliby obcym. To właśnie ta wspólnota „ciemnych sprawek” tworzy, według Michaela Herzfelda, „zażyłość kulturową"12. Metodę ciągłej obserwacji i bycia w pogotowiu, oczekiwania na "potknięcia” czy „fałszywe kroki” badanych świetnie opisuje Michael Jackson:

Żaden antropolog ani dziennikarz nie może uciec przed podejrzeniami, że jest kimś w rodzaju podglądacza. Podsłuchującym. Bo czyż nie mamy ciągle nadziei na to, że złapiemy naszą zdobycz znienacka, tak jakby prawda o osobie ujawniała się w momentach, w których uśpi ona swą czujność? ${ }^{13}$

Tak starałam się prowadzić badania - obserwowałam, uczestniczyłam w rozmowach internetowych, nasłuchiwałam, co ludzie powiedzą do siebie szeptem, wybierałam na zakupy z rodzinami, które właśnie otrzymały przekazy pieniężne od swoich krewnych, czy uczestniczyłam w uroczystym otwieraniu paczki z Ameryki. Wiedza etnograficzna jest budowana właśnie z tych codziennych sytuacji, przez nakierowanie uwagi na półświadome gesty, które z czasem stają się odróżnialne i zrozumiałe. Jackson nazywa to „doskonałą wzajemnością" (consummate reciprocity)), która znajduje wyraz w „zawartej w gestach, afektywnej i dialogicznej intersubiektywności"14.

Zaczyna się od prostych rzeczy - umiejętność odczytania znaczenia mrugnięcia okiem lub wzniesionej brwi, użycia właściwych słów w odpowiedzi, przybrania właściwej pozy ${ }^{15}$. Z czasem zmienia się nasz sposób użycia ciała, czego już nie zauważamy, reguły stają się przezroczyste; mniej się gubimy i popełniamy mniej gaf. Podczas badań, musiałam nauczyć się przede wszystkim dwóch rzeczy: trzymania emocji na wodzy, tak aby nie okazać złości czy zniecierpliwienia, oraz troski o to, aby inni czuli się ze mną dobrze, aby nie stracili twarzy. Ta troska o innych oznaczała wysiłek, by relacje z ludźmi przebiegały spokojnie i bezkonfliktowo, i jest jedną z podstawowych wartości funkcjonowania społecznego na Filipinach ${ }^{16}$.

12 M. Herzfeld Cultural intimacy.

13 M. Jackson In Sierra Leone, Duke University Press, Durham-London 2004, S. 132.

M. Jackson Minima ethnographica, s. 32-33.

15

C. Geertz The interpretation of cultures, Basic Books, New York 1973, s. 6-7.

M. Herzfeld The cultural politics of gesture. Reflections on the embodiment of ethnographic practice , "Ethnography” 2009 vol. 10 (2), s. 131-152. 
Do zrozumienia działania troski na odległość konieczne jest wyodrębnienie, za Rafaelem, dwóch kategorii migrantów: wieloletnich migrantów zadomowionych już w nowym kraju (balikbayans ${ }^{17}$ ) oraz pracowników kontraktowych, którzy w teorii pozostają za granicą tylko na czas kontraktu i wykonują raczej pracę manualną (Overseas Contract Workers). Ci pierwsi, balikbayans, są postaciami ambiwalentnymi - zazdrości się im, ale też często wywołują gniew, kiedy pokazują swoje nowe umiejętności społeczne lub starają się nie tylko „omamić tubylców”, ale i zmienić ich ${ }^{18}$. Te właśnie uczucia, które wywołują powracający emigranci, mają być trzymane na uwięzi - publicznie nie powinno się ich okazywać, pod groźbą sankcji społecznych. Spotkania z balikbayans są więc trudne i pełne napięcia. Rafael pisze wręcz, że są oni widziani

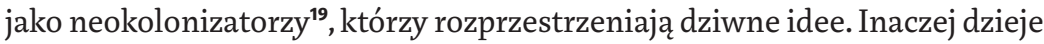
się z OCWs - ci widziani są jako bohaterowie, cierpiący trudy i poniżenie, poświęcający się dla swoich rodzin i dla kraju. To przeciwstawienie umożliwia widzenie migranckich praktyk troszczenia się w świetle ogromnych różnic klasowych, ale też pomaga zrozumieć konflikty pomiędzy emigrantami i ich rodzinami.

\section{Uczenie się poprzez radykalne niezrozumienie}

Wiedza antropologiczna budowana jest w momentach radykalnego niezrozumienia - momentach, kiedy nie rozumiemy znaczenia wydarzeń dziejących się przed naszymi oczami, jednak formują one nasze późniejsze rozumienie badanych zagadnień. Takie chwile zdarzają się każdemu badaczowi, ale szczególnie charakterystyczne są w początkowych miesiącach badań terenowych, kiedy to dopiero uczymy się zasad współżycia społecznego, nie rozumiemy jeszcze znaczeń, ale widzimy wagę zdarzeń, gestów czy słów, zauważamy

Słowo balikbayan to formalnie określenie emigrantów przebywających co najmniej rok poza granicami kraju i wynika z ustawodawstwa wprowadzonego na Filipinach w latach 70., za czasów Ferdynanda Marcosa, aby skłonić ludzi do odwiedzania kraju (ustawa zapewnia emigrantom m.in. ulgi podatkowe). W potocznym użyciu jest to termin dość ambiwalentny. Określenie to składa się ze słowa balik (powracać) i bayan (miasto lub naród).

V.L. Rafael "Your grief is our gossip." Overseas Filipinos and other spectral presences, w: White love and other events in Filipino history, Duke University Press, Durham-London 2000, s. 206-207.

Zob. tamże, s. 208-209. Balikbayans byli porównywani do pierwszych amerykańskich nauczycieli (Tomasites), którzy przybyli na Filipiny na samym początku XX w. Uczyli oni w pierwszych szkołach powszechnych i rozprzestrzeniali pogląd, że Filipińczycy mogą być Amerykanami, co m.in. doprowadziło do szerokiej akceptacji wartości amerykańskich. 
je i notujemy w głowie lub w notesie ${ }^{20}$. Są to często sytuacje konfliktowe, pełne napięcia, gdy nagle pojawia się przepaść między antropologiem i badanym. Konflikt jest tu nieuchronny: „Współudział i konflikt są więc dopełniającymi się biegunami intersubiektywności"21. Rozumieniu Innego i jego świata towarzyszy więc niezrozumienie i tarcie, charakterystyczne dla tej relacji.

Konflikt i dyskomfort są częścią składową metodologii antropologii, ponieważ badacz ciągle ich doświadcza w swojej praktyce badawczej. Poniżej opisuję jedno ze zdarzeń, które - mimo że błahe i z pozoru nieważne - utkwiło mi w pamięci i uparcie powracało w moich "notatkach mentalnych" (headnotes) $)^{22}$, tworząc antropologiczne rozumienie i wiedzę raczej w długotrwałym aktywnym procesie niż w ułamku sekundy.

Przebywałam wtedy w tak zwanym domu dolarowym, który wybudowała znajoma emigrantka, pod opieką jej rodziny na miejscu. Pewnego dnia zobaczyłam z tarasu dym unoszący się z dużego domu z czerwonym dachem, położonego w niedużej odległości od nas. Dałam od razu znać moim współmieszkankom i byłam pewna, że - co uważałam za oczywiste - wezwiemy straż pożarną. Jednak ku mojemu zdziwieniu reakcja współlokatorek była zupełnie inna: ze spokojem obserwowały dym i całą sytuację i wróciły do swoich przerwanych prac. Dla mnie było to zupełnie niezrozumiałe, czułam narastającą złość. Jak mogły nie widzieć tego, co ja tak wyraźnie widziałam. Starałam się jeszcze przekonać je do działania, ale wszelkie moje próby spełzły na niczym. Pójście do tego domu, oddzielonego wysoką trawą, było zbyt niebezpiecznie, zresztą nie znały drogi. Zadzwonić po strażaków nie mogły, bo nie miały telefonu straży ani adresu domu. Mówiły coś o tym, że nie wiadomo, skąd jest ogień, że może to tylko ktoś pali śmieci, ale ja nie chciałam tego słuchać. Nie rozumiałam zupełnie logiki czekania, w rozmowie z nimi byłam zdenerwowana i mówiłam głośniej niż zwykle, z większymi emocjami. W desperacji próbowałam nawet przekonać do mojego pomysłu sąsiada, ale on też nie wykazał zainteresowania. Po tym wszystkim byłam zupełnie zrezygnowana i zmęczona, poszłam na górę i obserwowałam dym i liżące prawie dach języki ognia. Jednak po jakimś czasie ogień przygasł, dymu było

20 Zob. T. Kohn Incomers and fieldworkers. A comparative study of social experience, w: Social experience and anthropological knowledge, ed. K. Hastrup, P. Hervik, Routledge, London 1994; J. Okely Fieldwork embodied, "Sociological Review” 2007 vol. 5, s. 65-79.

M. Jackson Minima ethnographica, s. 4. kings of anthropology, ed. R. Sanjek, Cornell University Press, Ithaca-London 1990. 
coraz mniej - wyglądało na to, że dom się nie zajął. Wieczorem przy kolacji moje współlokatorki zachowywały się inaczej niż zwykle - jakby coś chciały powiedzieć, ale nie mogły, były smutne i nierozmowne. Po wielu próbach dowiedziałam się, że chodziło o sytuację z rzekomym pożarem - uraził je mój brak zaufania, mój trochę podniesiony głos, wyrażony otwarcie gniew.

Mogłabym wyjaśniać znaczenie tego zachowania na różne sposoby - innym rozumieniem tego, co jest naszą powinnością i jakie działanie jest warte podjęcia, innym poczuciem przestrzeni i widzeniem zagrożenia, brakiem zaufania do instytucji i do państwa, ale też znajomością kontekstu filipińskiego prowincjonalnego miasta. Jednak zamiast tych wszystkich równie uprawnionych wyjaśnień, chcę się skupić na rozpoznaniu przedtekstowego w tym wydarzeniu. Poprzez to niezrozumienie dotknęłam czegoś, co jest w samym centrum relacji międzyludzkich, ale właściwie nie znalazło odzwierciedlenia w słowach. Wyczułam bardziej, niż usłyszałam to, że złamałam jakoś dane mi zaufanie, jednak zrozumienie tego, które reguły naruszyłam, zajęło mi sporo czasu. Zabrakło mi troski o innych, która ujawnia się w zapobieganiu okazywania złych emocji, szczególnie przy innych, unikaniu konfrontacji, dbaniu o dobre relacje.

Podobne przypadki radykalnego niezrozumienia zdarzały się częściej podczas pierwszych miesięcy moich badań, zdarzały się również między emigrantami i ich rodzinami. To właśnie te interakcje wskazywały, jakie pojęcia i metafory są najbardziej istotne dla relacji pomiędzy tymi, którzy zostają, i tymi, którzy wyjeżdżają: troska o innych, dług wdzięczności, rodzina. Troszczenie się znaczyło wsparcie finansowe, ale i nadzór nad tym, jak te pieniądze zostaną wydane; wysyłanie paczek i oczekiwanie w zamian wdzięczności; zapewnienie rodzinie dachu nad głową, a zarazem symbolu statusu i sukcesu emigranta; skupienie się na potrzebach rodziny bardziej niż na swoich. Troszczenie się znaczyło też dbanie o podtrzymanie relacji i o komfort drugiej osoby.

W niektórych sytuacjach odtwarzających troskę moi rozmówcy traktowali mnie jak kuzynkę z zagranicy. Wynikało to zarówno z mojego powiązania z migrantami z ich rodzin, jak i z mojego łamania zasad troszczenia się o innych - stawałam się więc osobą noszącą cechy długoletniego emigranta (balikbayan). Jest on, jak pisał Rafael, postacią ambiwalentną: uosobieniem dobrych i złych cech, jednocześnie bliski i bardzo daleki, znający zasady i je łamiący, a przy tym wszystkim będący wzbudzającym zazdrość symbolem sukcesu i rozwoju, modernizacji ${ }^{23}$. Spotkanie emigranta (lub antropologa) 
z rodziną w kraju może jednak stwarzać produktywne tarcie. Wyobrażenia i normy dotyczące troski przekazywane są wtedy przez cielesną obecność w terenie, a powstałe nieporozumienia i konflikty pozwalają lepiej widzieć badaną rzeczywistość.

\section{Przemiana wrażliwości}

Wiedzę antropologiczną tworzą obserwacja, mimikra, powtarzalność, jednak skoncentrowana jest ona w konkretnych zdarzeniach w terenie. Właśnie dzięki zdarzeniu możemy zrozumieć ważną właściwość życia społecznego, uchwycić ją w działaniu, za sprawą doświadczenia, i przez chwilę obserwować ją, kiedy nam się objawia. Csordas wskazuje na te chwile jako na czas, w którym dokonuje się „przemiana wrażliwości” (transmutation of sensibilities). Jak pisze, „zajmują one szczególną pozycję na kontinuum pomiędzy byciem zupełnie obcym a stawaniem się tubylcem [...], kiedy można doświadczyć świata w sposób zaskakujący i typowy dla środowiska, w którym prowadzi się badania"24.

Csordas opisuje takie chwile w czasie swoich badań, na przykład moment, kiedy w czasie pracy z katolicką grupą charyzmatyczną usłyszał proroctwo, a wszystko stało się zgodnie z regułami praktyk religijnych, które badał. Tak to komentuje: „Nie mogłem pomylić tego zjawiska z niczym innym, po tym, jak badałem je, słuchałem opowieści o nim, prowadziłem i przepisywałem wywiady na jego temat" ${ }^{25}$. Zrozumienie to było możliwe tylko dlatego, że zdobył on praktyczną wiedzę w rozpoznawaniu elementów charyzmatycznej praktyki religijnej, a w konsekwencji także wiedzę o tym, jak powinny one przebiegać: nagły „wzrost empatii dla ich walki” był możliwy tylko dlatego, że Csordas zyskał kompetencję w rozpoznawaniu proroctw, a w konsekwencji wiedzę na temat tego, jak powinny one przebiegać:

Głównym czynnikiem jest to, że badałem ten gatunek mowy rytualnej i cały system, w którym ona funkcjonuje, dostatecznie dokładnie, tak że - bez uświadamiania sobie tego - przyjąłem zarówno konwencje tych zachowań, jak i ich performatywne dyspozycje. ${ }^{26}$

T. Csordas Transmutation of sensibilities: Empathy, intuition, revelation, w: The shadow side offieldwork. Exploring the blurred boundaries between ethnography and life, ed. A. McLean, A. Leibing, Blackwell Publishing, Oxford 2007, s. 106-107.

25 Tamże, s. 108. 
Koncepcja przemiany wrażliwości pozwala mi analizować własne doświadczenia terenowe i rozpoznać momenty, w których tworzyła się wiedza antropologiczna. To właśnie te rzadko pojawiające się i niespodziewane chwile, w których czujemy, że współdzielimy z badanymi pewną modalność i rozumienie rzeczywistości, prowadzą nas ścieżką przedtekstowości ku możliwościom intersubiektywnego zrozumienia.

Jedną z ważnych codziennych praktyk migrantów jest utrzymywanie kontaktu z rodzinami w kraju, obserwowanie i uczestniczenie w rozmowach prowadzonych za pomocą komunikatorów internetowych stało się więc i moim udziałem. W rozmowach tych ujawniają się różne motywacje i dyskursy - poświęcenie dla rodziny, wybór materialnego wsparcia zamiast fizycznej bliskości, tęsknota i chęć wyrwania się ze zbyt ograniczających więzi rodzinnych, plany indywidualne versus strategia rodzinna. Komunikacja na odległość służy zatem nie tylko do bycia w kontakcie, ale także do nadzorowania i dyscyplinowania członków rodziny.

Nadzór powodował opór: uczestniczący w spotkaniach online członkowie rodzin potrafili unikać niewygodnych tematów i patrzenia w oczy, ale także rozmów czy włączenia kamery internetowej. Takie strategie oporu stosowali głównie ci, którzy byli intensywnie obserwowani i upominani. Bawienie się komórką, spuszczenie głowy, udawanie, że kamera internetowa jest zepsuta to wszystko świetne metody uniknięcia konfrontacji. Z czasem widziałam, jak bardzo rozmowy te irytują ich, zawstydzają, zasmucają, ale jak bardzo też starają się oni to ukryć przed tymi, którzy wspierają ich z zagranicy, bo wiedzą, że pokazanie takich emocji nie jest właściwie możliwe bez narażenia relacji na zerwanie lub przynajmniej ochłodzenie.

W czasie rozmów przez internet emocje przekazywane są za pomocą gestów, mimiki, ułożenia ciała - zauważenie ich wymaga ciągłej uwagi, łatwo można je pominąć w analizie. Istotność drobnych gestów dobrze ilustruje jedna z obserwowanych przeze mnie rozmów między matką a nastoletnim synem. Matka, wprowadzona w błąd przez rodzinę, że jej syn ma złe oceny (akurat tego dnia nie była to prawda, ale kłopoty w szkole mu się zdarzały), woła go „na dywanik" przed kamerkę i z tłumioną złością wymawia mu jego nieodpowiedzialność. Syn siedzi przed ekranem komputera, trochę zawstydzony, a trochę jakby obojętny, wpatruje się w ekran i nie odpowiada na matczyne uwagi.

W tym czasie inni członkowie rodziny (wujkowie, ciotki, kuzyni) śmieją się na boku, ciesząc się, że żart tak bardzo się udał. Matka obejrzała oceny innego chłopaka z rodziny, ale pokazali jej tylko oceny spisane na karcie 
semestralnej, bez imienia i nazwiska - zalety tego, że wie się, jak użyć kamerki na Skypie, żeby pokazać tylko tyle, ile się chce. Oprócz maestrii w używaniu narzędzi internetowych sytuacja ta pokazuje, jak bardzo trudne i pełne napięcia są rozmowy na odległość - filipińskie żartowanie (making bola) ma na celu ukrycie całej gamy negatywnych uczuć, od smutku, złości, zawodu do niepokoju i zazdrości.

W całej tej sytuacji syn nie mógł zaprzeczyć swojej matce, zezłościć się, mimo że zawstydzała go przy innych, w dodatku niesłusznie. Tyrada matki wyrażała troskę o niego. Chłopak udawał, że jej słowa go nie dotykają. W całej sytuacji - pomimo ogólnej wesołości - widać było głęboką więź między matką a synem i że to właśnie te minuty rozmów online służą budowaniu i potwierdzaniu tej relacji. W czasie gdy matka mówiła, chłopak zataczał na ekranie kursorem koła wokół jej twarzy. Wydawało się, że tym kursorem dotyka twarzy matki, zapamiętuje jej kształt, stara się ją ułagodzić. Komunikacja mediowana za pomocą komputera stała się w pewien sposób doświadczeniem cielesnym. Matka nie widziała tego, gdy patrzyła na swój ekran, ale dla niego było to, jak się wydaje, potwierdzenie tej relacji. Nagranie tej rozmowy i obejrzenie jej później pozwoliło mi wychwycić moment, w którym intymna intersubiektywna relacja troski staje się namacalna dzięki nowym mediom, a nieobecna migrantka staje się obecna w domu rodzinnym.

Logika troski obecna w filipińskich rodzinach migranckich, która uobecniała się w takich przypadkach, od początku zwracała moją uwagę, a nawet w pewien sposób mnie fascynowała. $\mathrm{O}$ fascynacji w procesie zdobywania wiedzy terenowej pisze Jennifer Mason:

Bycie zafascynowanym nie jest neutralnym zainteresowaniem. Jest to zaangażowana, afektywna forma dociekliwości, która emanuje od źródła fascynacji czy też fascynującego zbioru relacji, a także z naszych skłonności i doświadczeń bycia w świecie i obserwowania go. ${ }^{27}$

Mason pisze o „fascynacji” i „byciu nawiedzonym” przez pewne idee, o niemożności pozbycia się ich, a więc o długotrwałym procesie nabywania wiedzy antropologicznej, procesie przedtekstowym, kiedy dopiero się ona tworzy, zanim skrystalizuje się w formie wywodu teoretycznego. Pojęcia i praktyki związane z troską w taki właśnie sposób krążyły wokół mnie i nie dawały mi

27 J. Mason Knowing the in/tangible, Working paper no. 17, Morgan Centre, University of Manchester, Manchester 2011, s. 4. 
spokoju. „Przemieniające rozpoznanie” (transformative recognition) może wydarzyć się tylko wtedy, gdy pozwolimy sobie podążyć za zainteresowaniem, uwagą, intuicją. Za Taussigiem Mason mówi o „niemożliwym do powstrzymania łączeniu się obiektu percepcji z ciałem tego, który dostrzega”, co „wskazuje na rodzaj niewiedzącej wiedzy [...] właśnie dlatego, że nie wiedziałeś dopóki cię to nie uderzyło albo dopóki nie wypaliło się w tobie"28.

\section{Poznawanie poprzez ciało}

Metafora wiedzy „wypalającej się” w ciele (searing itself into you) świadczy o ucieleśnionym charakterze wiedzy antropologicznej i wskazuje też, jak możemy uczyć się poprzez cielesne doświadczanie i odczuwanie. Aby osiągnąć lepsze porozumienie z badaną społecznością i lepiej zrozumieć jej rzeczywistość społeczną, antropolog sięga po różne metody - uczenie się języka, dopasowywanie swojej postawy do tego, co dzieje się wokół, naśladowanie gestów i grymasów twarzy, ograniczanie lub uwalnianie ciała. Jak pisze Herzfeld, to właśnie „te aspekty gestów, a w szczególności zetknięcie gestów z przestrzenią społeczną, warunkują wytwarzanie wiedzy etnograficznej"29. W naszym wysiłku, by być jak Inni, możemy doświadczyć momentów, kiedy uczestniczymy w innej modalności, kiedy udaje nam się uchodzić za tubylca, nie za obcokrajowca, nawet pomimo naszego odmiennego wyglądu.

Momenty takie zdarzają się w czasie badań, co dobrze ilustruje przykład podany przez Michaela Herzfelda: w przytaczanej sytuacji słyszy, że wygląda jak Taj, bo nie tylko używa ich języka, ale i gestów ${ }^{30}$. Uczymy się poruszać w nieznanym nam otoczeniu, a z czasem czujemy się w nim coraz bardziej swobodnie. Kiedy wiedza ta staje się ucieleśniona, proces intersubiektywnego rozumienia może się zacząćs1.

W badaniach migracji antropolog musi pracować w dwóch modalnościach - modalności migranta i modalności jego środowiska w kraju pochodzenia. Mój sposób zachowania, na początku dzielony głównie z migrantami pracującymi w Bostonie, powoli się zmieniał, tak że później włączyłam do sposobu bycia także oczekiwania, przekonania i zasady zachowania, którymi

28 Tamże, s. 10.

29 M. Herzfeld The cultural politics of gesture, s. 133.

30 Tamże, s. 141.

31 J. Okely Fieldwork embodied. 
kierują się rodziny emigrantów w codziennym życiu. Ten proces nauki był wzmacniany w momentach interakcji emigrantów z ich rodzinami, kiedy często dochodziło do tarć i konfliktów. Z czasem, starając się dopasować do tego, jak ludzie wokół mnie poruszali się, mówili, i wyrażali swoje opinie, czułam się lepiej w rzeczywistości filipińskiej, zaczęłam też rozumieć logikę zachowań rodzin emigrantów na Filipinach.

W kolejnym akapicie proponuję bliższe przyjrzenie się sytuacji, w której jako antropolożka byłam zawstydzona zachowaniem jednej z moich rozmówczyń emigrantek, ponieważ jej zachowanie nie spełniało przyjętych norm : nie było w nim wymaganej troski o ludzi wokół, nie było próby uniknięcia konfliktu i konfrontacji, nie było przesunięcia siebie na drugi plan. Wtedy bliżej mi było do tego, co odczuwają krewni emigrantki i ludzie wokół niej, niż do tego, co czuje ona sama.

Podróżując z emigrantami odwiedzającymi Filipiny po kraju i odwiedzając ich rodziny, miałam możliwość porównać moje nowo nabyte umiejętności zachowania się w tym kontekście kulturowym z umiejętnościami emigrantów. Jedną z nich była Concepcion. Wyjechała z Filipin jako nastolatka adoptowana przez ciotkę. W rezultacie Concepcion ma w Stanach Zjednoczonych matkę zwaną po angielsku mother i drugą, biologiczną, matkę na Filipinach, którą nazywa po filipińsku nanay i którą odwiedza raz na kilka lat. Towarzyszyłam jej w jednej z takich wizyt. Widziałam, jak niezręcznie czuje się ona z rodziną matki, szczególnie wtedy, gdy proszą ją o pieniądze. Nie chciała na przykład płacić za wspólne obiady w restauracji, uważała, że płaci tylko za siebie, mamę i za mnie. Nie czuła takiego wymogu pomagania rodzinie jak niedawni emigranci, którzy dopiero wyjechali z kraju na kontrakt za granicą. Jej definicja troski była daleka od oczekiwań jej krewnych.

Historia Conception dobrze pokazuje zmiany w praktykach życia codziennego, ideach i podejściu spowodowanych migracją, i co dzieje się w zetknięciu tych dwóch światów ${ }^{32}$. Dla mnie w tych sytuacjach była ona uosobieniem wartości amerykańskich: indywidualizacji, prywatności, skupienia na sobie, robienia wszystkiego na czas. Była tym wszystkim, czym ludzie wokół niej nie byli (ale do czego aspirowali). Nie mówiła po filipińsku dość dobrze, nie starała się zniknąć wśród ludzi, nie chciała nikogo zadowolić, tak jak ja, dostosowując się do obowiązujących ideałów dobrych relacji jako relacji bezproblemowych (smooth interpersonal relationships) ${ }^{33}$.

Zob. P. Levitt The transnational villagers. 
W czasie naszej wspólnej podróży odczuwałam tę nieprzystawalność świata migranckiego do świata niemigranckiego wręcz cieleśnie: poczucie, że coś jest nie tak, dyskomfort, dziwność niektórych sytuacji. Potwierdzał to fakt, że niektórzy członkowie rodziny Concepcion, nie chcąc się z nią konfrontować, zwracali się do mnie z prośbą, żeby jej coś przekazać czy wytłumaczyć, w nadziei, że jakoś na nią wpłynę.

Niebycie w zgodzie z regułami troski zdarzało się Concepcion przy wielu okazjach, nie tylko w sytuacjach rodzinnych. Jedno z takich wydarzeń zapisało się szczególnie mocno w mojej pamięci, ponieważ bardzo odczułam wtedy zażenowanie z powodu nieprzestrzegania norm troski o innych. Byłyśmy na dwudniowej wycieczce nad morze, w miejscu dość odosobnionym. Żeby dostać się z powrotem do głównego miasta prowincji, musiałyśmy przejechać motorem z przyczepką przez góry, przepłynąć godzinę łodzią, a później jechać przez kilka godzin samochodem. Kiedy pojawiłyśmy się na przystani jakieś 20 minut przed odpłynięciem statku, okazało się, że wszystkie miejsca są już zajęte i kasjer nie może nam sprzedać biletu. Sytuacja była trudna i stresująca, bo późnym popołudniem miałyśmy już samolot do Manili. Obie byłyśmy bardzo przejęte, jednak ja zaakceptowałam fakt, że trzeba będzie czekać, Concepcion natomiast postanowiła działać. Zaczęła od dyskusji z mężczyzną sprzedającym bilety i nie ukrywała swojego zagniewania. Wszyscy rozmawiający z nią i przysłuchujący się temu zdawali się wzdrygać i kurczyć, żeby nie być obiektem gniewu - widać było wyraźnie, że gniewna konwersacja bardzo im nie odpowiada. Cała ta sytuacja była dla mnie bardzo trudna, ponieważ wiedziałam i czułam, że robimy wszystko to, czego nie powinnyśmy, zmuszając ludzi do wyjścia ze swojej strefy komfortu. Przychodził mi na myśl opis z artykułu Rafaela, jak powracający migranci wydają się aroganccy i bezwstydni: „pogrążeni we własnym poczuciu wyższości wywołują jedynie u innych uczucie zazdrości"34, podczas gdy oni tylko odtwarzają nowe wzorce zachowań i wartości przywiezione ze sobą.

W tamtej sytuacji doświadczyłam dyskomfortu także na poziomie fizycznym - chciałam stamtąd uciec, stać się mniejsza, zniknąć. Później Concepcion wmieszała w tę sprawę jeszcze kogoś z obsługi portu, który podwiózł nas pod statek, gdzie moja towarzyszka próbowała namówić ludzi do odsprzedania nam miejsc. Cały czas filmowała, co tylko wzmacniało niezręczność całej sytuacji. W końcu jej próby zostały nagrodzone sukcesem: ludzie na statku, może zmęczeni całą sprawą, ścisnęli się na swoich miejscach, więc znalazło się tam miejsce dla nas.

34 V.L. Rafael „Your grief is our gossip”, s. 207-208. 
Zachowanie Concepcion stanowi bardzo dobrą ilustrację sytuacji, w której znajdują się emigranci żyjący transnarodowo, pomiędzy dwoma światami: doświadczają oni z jednej strony tęsknoty za domem i ojczyzną, z drugiej zaś trudno im poczuć się naprawdę „w domu” w kraju z wyobrażeń. Zmiany w zachowaniu, postawach i wartościach balikbayans odkrywane są przypadkiem w codziennych interakcjach: dochodzi wtedy często do konfliktów z krewnymi. Jako antropolożka ja też powodowałam niezręczne sytuacje i dyskomfort wśród rozmówców, kiedy nie stosowałam się do reguł troszczenia się, jednak to dzięki tym sytuacjom radykalnego niezrozumienia mogłam rozpoznać kształt troski jako idei porządkującej życie codzienne migrantów i ich rodzin.

Powyższe opowieści są przykładem „przemiany wrażliwości”, kolejnym krokiem na drodze etnografa do rozumienia. Aby ujawnić reguły rządzące życiem społecznym, potrzeba właśnie takich momentów - momentów spotkania, kiedy w jakiś sposób można dotknąć relacji społecznych wokół. Do świata Innego możemy wejść tylko na chwilę, jednak to ta chwila kształtuje w największym stopniu naszą wiedzę i prowadzi nas w kierunkach trudnych wcześniej do przewidzenia.

Jak dowodzi Thomas Csordas, otwarcie się na ciemną stronę etnografii tworzy „zrąb intersubiektywności”, która pozwala na stworzenie mocnej więzi, także nieprzewidzianej ${ }^{35}$. Starałam się w tym artykule pokazać przykłady takich właśnie więzi, kiedy jako antropolożka zaczynałam czuć, że moje lub czyjeś zachowanie mieści się w dopuszczalnych ramach albo nie, a tę nieprzystawalność odczuwałam wręcz cieleśnie. Poprzez uwagę poświęconą ucieleśnionym codziennym praktykom starałam się zrozumieć to, co przedtekstowe: to, co nie było wypowiadane na głos, ale mogło być odczuwane i odkrywane dzięki długotrwałemu udziałowi w codziennych działaniach i pewien rodzaj uważności. Zrozumiałam, jakiej troski oczekuje się na Filipinach i dlaczego sposób działania migrantów może być nieakceptowalny przez nie-migrantów: łamią oni zasady troszczenia się o innych, ale tym samym umacniają je i potwierdzają ich istnienie. 


\section{Abstract}

\section{Helena Patzer}

CZECH ACADEMY OF SCIENCES, UNIVERSITY OF WARSAW

An Encounter with the Pretextual: Creating Ethnographical Knowledge about the World of Migrant Care

The article focuses firstly on the meaning of 'caring' in the context of Filipino migration to the United States and, secondly, how 'proper care' is learned, how one breaks the rules of care, and what consequences this might have. This is also a methodological contribution: drawing on studies of transnational migration, Patzer analyses how care practices are revealed through everyday encounters with immigrant and non-immigrant family-members and how it is created in a pretextual way before it can be even named and described.

\section{Keywords}

migration, transnationalism, long-distance care, pretextual ethnography 